\title{
Tracing the Growth of Sarawak Pepper
}

\author{
Rhemaneeta Allan, Adrian Daud, Neilson Teruki, Aryaty Alwie, Suraya \\ Hanim, Ribka Alan
}

To Link this Article: http://dx.doi.org/10.6007/IJARBSS/v11-i17/11388

DOI:10.6007/IJARBSS/v11-i17/11388

Received: 09 August 2021, Revised: 30 August 2021, Accepted: 23 September 2021

Published Online: 20 October 2021

In-Text Citation: (Allan et al., 2021)

To Cite this Article: Allan, R., Daud, A., Teruki, N., Alwie, A., Hanim, S., \& Alan, R. (2021). Tracing the Growth of Sarawak Pepper. International Journal of Academic Research in Business and Social Sciences, 11(17), 2734.

\section{Copyright: (C) 2021 The Author(s)}

Published by Human Resource Management Academic Research Society (www.hrmars.com)

This article is published under the Creative Commons Attribution (CC BY 4.0) license. Anyone may reproduce, distribute, translate and create derivative works of this article (for both commercial and non-commercial purposes), subject to full attribution to the original publication and authors. The full terms of this license may be seen at: http://creativecommons.org/licences/by/4.0/legalcode

Special Issue Title: Empowering Community and Beyond, iRandau, 2021, Pg. 27 - 34 


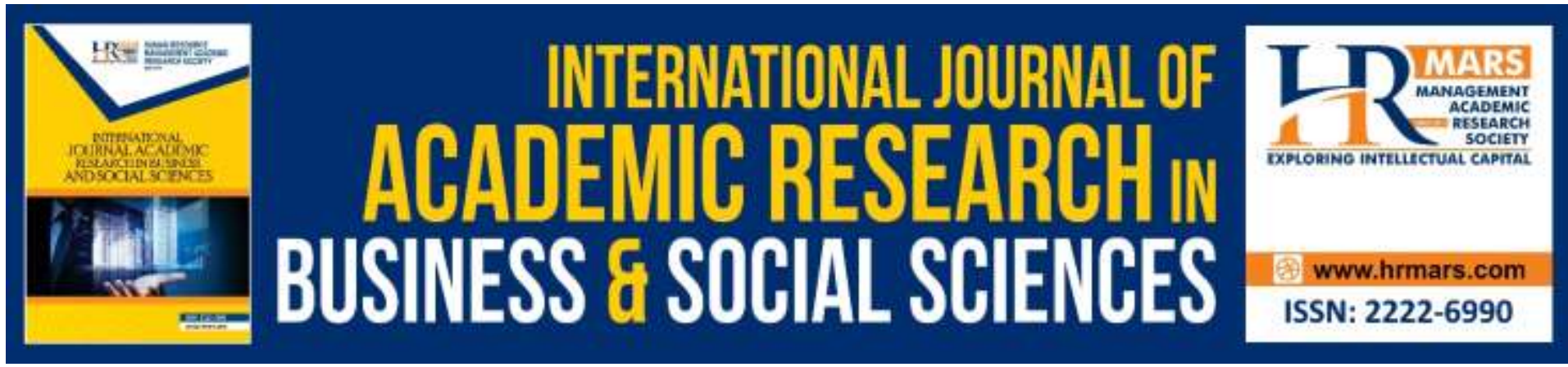

\title{
Tracing the Growth of Sarawak Pepper
}

\author{
Rhemaneeta Allan ${ }^{1}$, Adrian Daud ${ }^{1,2}$, Neilson Teruki ${ }^{1}$, Aryaty \\ Alwie $^{1}$, Suraya Hanim ${ }^{1}$, Ribka Alan ${ }^{1}$ \\ ${ }^{1}$ Department of Social Science and Management, Faculty of Humanities, Management and \\ Science, Universiti Putra Malaysia Bintulu Sarawak Campus, Nyabau Road, 97008 Bintulu, \\ Sarawak, Malaysia, ${ }^{2}$ Institut Ekosains Borneo, Universiti Putra Malaysia Bintulu Sarawak \\ Campus, 97008 Bintulu, Sarawak, Malaysia. \\ Email: adrian@upm.edu.my
}

\begin{abstract}
This study was done to analyse the growth performance of Sarawak white and black pepper from the year 1990 to 2019. Compound Annual Growth Rate (CAGR) method was used to measure the growth performance. From the study, it is found that the area of cultivation and local consumption have increased for the overall period by 1.531 percent and 10.016 per percent per annum. The production and export performance for the overall period have decreased by -0.879 percent and -3.501 percent per annum. The findings suggest that an apt price stabilizing policy needs to be enacted to protect pepper producers from experiencing the negative impact of price fluctuations.
\end{abstract}

Keywords: Sarawak Pepper, Compound Annual Growth Rate, Production.

\section{Introduction}

Pepper or also known as Piper nigrum L, is originated from the Western Ghats of India. It is known as the oldest King of spice because of its uses and values in the olden days till now (Nair, 2020).

Pepper plants are widely cultivated in many tropical climate countries such as India, Brazil, Indonesia, Sri Lanka, Malaysia, Vietnam, and China. These are some of the countries that are producing pepper mainly for exports and partly for the local consumption.

This perennial plant adapts and grows well between $20^{\circ}$ North to $20^{\circ}$ South of the equator, which are of tropical temperate. It adapts well at $1500 \mathrm{~m}$ above sea level. Pepper plant also requires rainfall between 2000 to $3000 \mathrm{~mm}$ with a suitable environmental temperature between $23^{\circ} \mathrm{C}$ to $32^{\circ} \mathrm{C}$ (Sivaraman, Kandiannan, Peter, \& Thankamani, 1999). This plant is very sensitive to drought and flood. It is usually planted on slopy hills where there is water flow with minimal waterlogs, or on grounds with excellent drainage system. The pepper vines can reach up to 10 meters height and survive for 15 years or even longer (Nair, 2020). In Malaysia, the vines are main cultivated using ironwood poles, which are non-living standards in a monocropping system.

This valuable crop was introduced to Malaysia in the $19^{\text {th }}$ century during the rule of James Brooke. Currently, the state of Sarawak is well known for its pepper quality and production globally. The name 'Sarawak Pepper' is known globally due to the high-quality pepper 
produced in this region. Sarawak produces 24,000 tonnes which is approximately 97 percent of the total production in Malaysia (Department of Statistic Malaysia, 2019). In Sarawak, there are 37,847 farmers who are relying on this crop to earn a living (Malaysian Pepper Board, 2018). This commodity contributes a significant amount of income to the state and to the nation which is about 35.2 million USD from its export. Malaysia is currently on $5^{\text {th }}$ rank for pepper export (International Pepper Community, 2019).

\section{Literature Review}

Despite having a well-known quality pepper, Sarawak has been experiencing some major issues in its production and marketing of product. Low price, high competitiveness, low production, low local consumption are some of the struggles experience by the industry (Entebang, et al., 2020). Pepper production will continue to grow as there is continuous demand for it. The high demand for pepper has driven pepper price in the past and this has led to the all-time high world pepper price in 2015. Increase in production by major producers that subsequently followed contributed to the declining of the price since then. Gulick (2018) showed that by 2018, the global consumption of pepper is well below the production. Apart from the food industry, pepper is being used in other industries such as cosmetics and its oil has been used in perfumes (Khalid et al., 2007). The non-food usage of pepper such as this will be a key factor in maintaining demand in the future. Liew (2020), as quoted by The Star said that there are more than 40 pepper agropreneurs in Sarawak involved in downstream activities.

Pepper production for the period of 2015-2017 in Malaysia was partly motivated by the price hike (Entabang, et al., 2020) and with the oversupply of production we have seen that price was down by more than $50 \%$ than the price in 2015 . The fall in the price in recent years discourage farmers into increasing production but despite this, the overall production is projected to increase in the long run. Sukmawan, \& Hyesun (2020) argued that increase in pepper plantations and productivity will drive this growth. The growth performance of a cash crop indicates the expansion or reduction of a particular commodity over period of years. It is important to evaluate the performance rate of a cash crop in terms of growth in area, production, consumption, and export, to ensure sustainable productivity and development in economy and agricultural perspective. Agricultural growth can be dampened if profitability in the industry is declining because of low prices (Babu et al., 2014).

\section{Methodology}

This study aims to measure the growth of pepper and will indicate the trend and direction of the commodity over a period of time. To evaluate growth of the pepper market, we will look at area (of cultivation), production, local consumption and export. Secondary data on annual prices from the year 1990 to 2019 were collected from the Malaysian Pepper Board and International Pepper Community. The Compound Annual Growth Rate (CAGR) is used to measure the mean annual growth rate over a period of time. The formulae for the CAGR is calculated as follows:

$$
Y=a b^{X}
$$

where, $Y$ is the quantity or values of the variable for which the growth rate was calculated. $X$ represents the time period of the variable in years. While $a$ is the constant of the equation and $b$ is the coefficient value. Hence the Compound Annual Growth Rate is obtained as:

$$
\operatorname{CAGR}(\%)=\left(\text { Antilog } ' b^{\prime}-1\right) \times 100
$$


The 30-year period will be divided into three different periods as to reflect the growth in each of the decade. This will enable us to have a closer look at the different time periods instead of an overall overview as there are bound to be volatility in agricultural commodities such as pepper. For production and export (i.e., the products) we further divide them into both black and white pepper.

\section{Results and Discussion}

Pepper has been a vital source of income for small scale farmers in Sarawak. Trend analysis for the area, production, local consumption, and export for a period of 30 years was analysed using CAGR. The results are shown in Table 1.

Table 1: Estimated Compound Annual Growth rate of Area, Production, Consumption and Export

\begin{tabular}{|c|c|c|c|c|c|c|c|c|}
\hline \multirow{2}{*}{ Year } & \multirow{2}{*}{ Area } & \multicolumn{3}{|c|}{ Production (M.Tons) } & \multirow{2}{*}{$\begin{array}{l}\text { Consumpti } \\
\text { on } \\
\text { (M.Tons) }\end{array}$} & \multicolumn{3}{|c|}{ Export (M.Tons) } \\
\hline & & Black & White & Total & & Black & White & Total \\
\hline $\begin{array}{l}1990- \\
1999\end{array}$ & -0.249 & -6.172 & 6.172 & -3.984 & 6.172 & -5.375 & 3.206 & -0.980 \\
\hline $\begin{array}{l}2000 \\
- \\
2009\end{array}$ & 1.888 & -3.640 & 11.390 & -0.962 & 18.135 & -7.112 & 2.174 & -1.731 \\
\hline $\begin{array}{l}2010 \\
- \\
2019\end{array}$ & 2.995 & -3.356 & 9.534 & -1.300 & 24.513 & -11.254 & 0.302 & -3.145 \\
\hline $\begin{array}{l}\text { Overa } \\
\text { II }\end{array}$ & 1.531 & -1.475 & 1.950 & -0.879 & 10.016 & -3.979 & -0.223 & -3.501 \\
\hline
\end{tabular}

During the first period which is from 1990 to 1999 , there has been a decline in area by -0.249 percent per annum. The decline in area has directly influence the production of pepper by causing a decrease of -3.984 percent per annum. The total decline in the production of black pepper during the period was by -6.172 percent per annum, yet there was a significant increase in the production of white pepper by 6.172 percent per annum.

During the first period, the export of black pepper also had experienced a decline of -5.375 percent per annum. The overall decline of export of pepper was by -0.98 percent per annum. Yet again, the export of white pepper increased by 3.206 percent per annum.

For the second period which is from the year 2000 to 2009, there has been an increase in the area of plantation which is by 1.888 percent per annum. Meanwhile, the production of black pepper decreased by 3.640 percent per annum and white pepper increased by 11.39 percent per annum. During the period, there has been an overall decline of 0.962 percent per annum in the production of pepper. The local consumption during the second period increased significantly by 18.135 percent per annum. While the export of black pepper declined by 7.112 and white pepper increase by 2.174 percent per annum. The overall export of pepper of the second period records a decline of 1.731 percent per annum. 


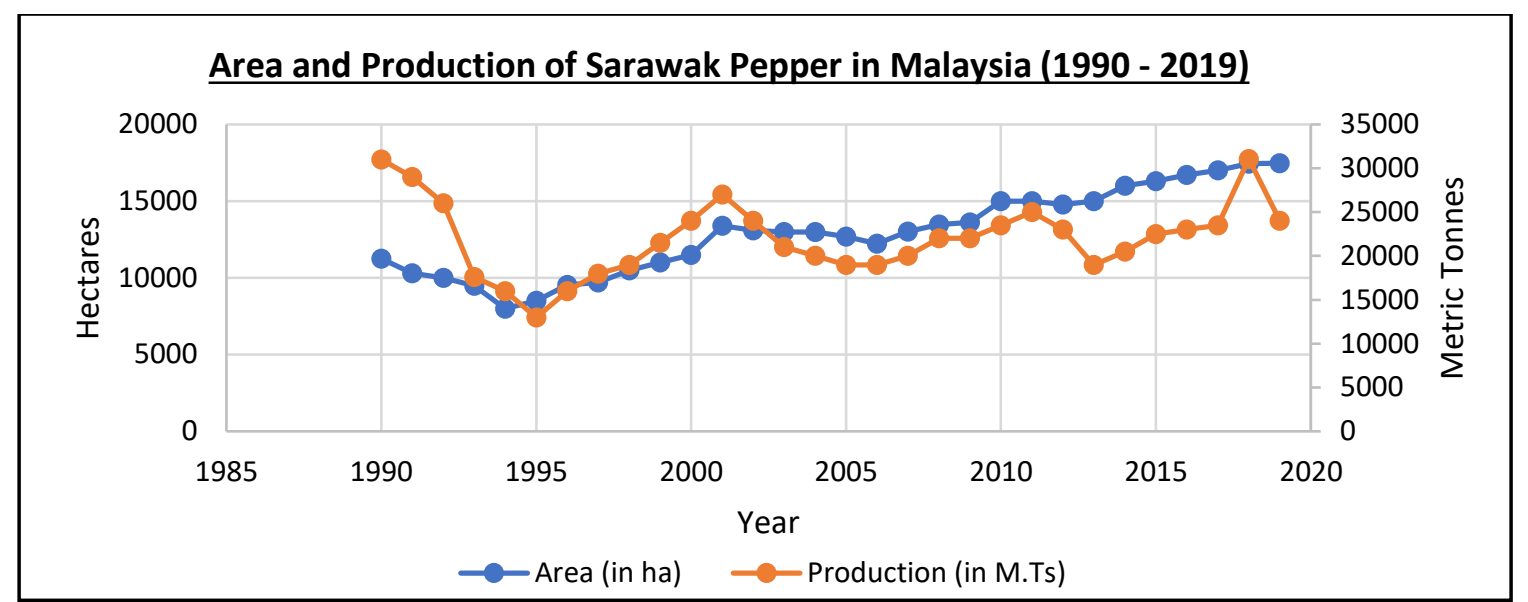

Figure 1: Area and production of Sarawak Pepper (1990 - 2019)

During the third period which is from 2009 to 2019, there is a significant increase of area by 2.995 percent per annum. Meanwhile, the production of black pepper continues to decrease by 3.356 percent per annum and white pepper records another continuous increase by 9.534 percent per annum. The overall production of pepper during the third period again recorded a negative growth of 1.3 percent per annum. The local consumption records the largest increase at 24.513 percent per annum compared to all three periods. Whereas the export of black pepper recorded a negative for the third time by a decline of 11.254 percent per annum, while white pepper exports recorded a partial growth of 0.302 percent per annum. Yet again, the overall exports of pepper for the period showed a decline by 3.145 percent per annum.

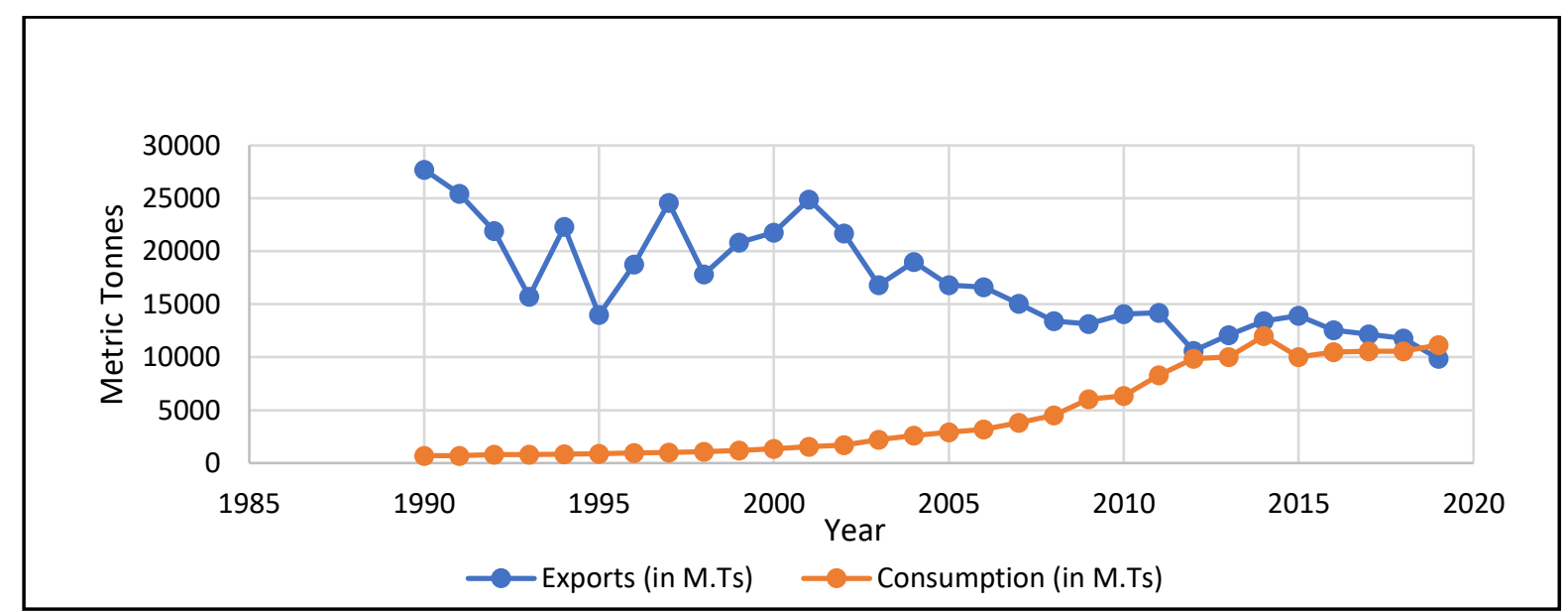

Figure 2: Export and local consumption of Sarawak Pepper (1990 - 2019)

Throughout the three decades, there has been a growth of 1.531 percent per annum for area of pepper plantation. Even so, the pepper production has recorded a negative growth of 0.879 per annum with -1.475 and 1.95 percent per annum on black and white pepper. A growth in area of plantation should result in an increase of production, yet the total production rate has indicated a decrease (see Figure 1). This scenario can be due to pest and disease infestation, unstable weather condition and poor management of pepper plantation by farmers.

Besides that, a change in price can also alter the rate of production (see Figure 3). Low pepper price will result in many farmers operating below optimum level. Due to lower returns, 
farmers tend to use lower inputs which will lower the efficiency in production of a farm, and this has been highlighted by Entebang et al (2020). Meanwhile, a high price will invite new farmers to invest in pepper plantings, and previous owners to maintain farms and purchase more inputs for optimal production.

The local consumption of pepper in Malaysia has seen growth throughout all three decades. Annual growth of 10 percent in local consumption is an indication that the commodity is becoming popular among the local people and food industries. A growth in consumption is also an indication of increasing demand. A significant increase in demand will lead to a higher equilibrium in price without a significant increase in supply. Increasing local consumption can lead to price sustainability in the domestic market.

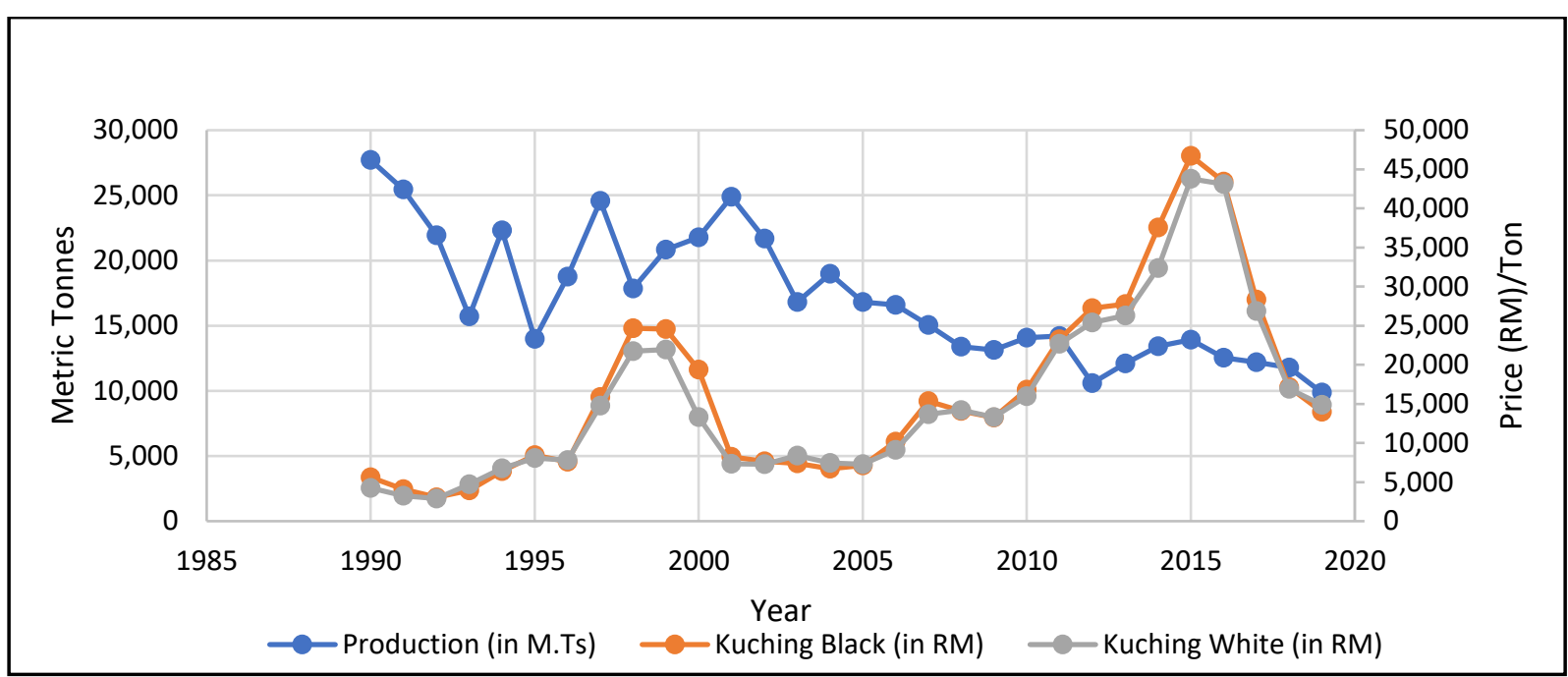

Figure 3: Price performance and production rate of Sarawak Pepper (1990 - 2019)

Meanwhile, the export of pepper has shown a negative growth in terms of quantity and value. There are various reasons that have led to the negative growth in export. Over the decades, pest infestation has been a major problem. This problem has led to poor quality yield, ranging below the stipulated quality measures. The use of pesticide does help in producing export quality, but the sensitivity of the international community on pesticide use should be a motivation for Malaysia to adopt good agriculture practices (GAPs) to remain competitive in the export market.

\section{Conclusion}

In 1969, Malaysia was ranked 1st as producing and exporting country. Malaysia was exporting more than 30 thousand tonnes of pepper during the 60 's and the 70 's. A historical overview showed that Malaysia and Indonesia were taking turn as world leader in producing pepper during these two decades. In 1980, Malaysia's export began to decline with Brazil and India coming into the market. Currently, Malaysia is ranked as 5th in terms of volume of export with an export of 7,886 tonnes of black pepper and 1,972 tonnes of white pepper. As Malaysia is still an important global player in terms of pepper production, it is important to maintain a consistent growth in term of production and export while aiming to protect the local smallholders from the effect of price fluctuations. The growth performance for area and local consumptions were positive for the overall period with a growth of 1.531 and 10.016 per annum. Production and export recorded negative growth for overall period with -0.879 and -3.501 per annum. Meanwhile the price movements were found to be cyclical 
throughout the period Price stabilization policy is an option to help local farmers from the negative impact of price fluctuation. Policy implementation has led to successful effort in reducing price volatility and this can influence the welfare of the smallholders (Abokyi et. al, 2018). Profit will be affected in a volatile market and price stabilization can lead to higher profit (Grega, 2002). This also depends on the ability of the local government to come up with a policy such as a buffer stock policy for example. This explains why efforts to promote price stability has been less successful in the 80 s and 90 s as it become not feasible in a long period of low price internationally (Troster, 2018). Price stabilization policy often involves the international market and trade policy will definitely affect stabilization policy as argued by Gouel (2013). However, this should not stop any effort to continue to support local smallholders to ensure the stability of the industry domestically. This stability will also include the roles of cooperatives in helping farmers to be successful.

\section{Acknowledgement}

This research was funded by GP-IPB. Pusat Kos 9557600.

\section{References}

Abokyi, E., Folmer, H., \& Asiedu, K. T. (2018). Public buffer stocks as agricultural output price stabilization policy in Ghana. Agriculture \& Food Security 7, 69. https://doi.org/10.1186/s40066-018-0221-1

Babu, S. C., Gajanan, S. N., \& Sanyal, P. (2014). Chapter 3 - Effects of Commercialization of Agriculture (Shift from Traditional Crop to Cash Crop) on Food Consumption and Nutrition Application of Chi-Square Statistic. In Babu, S.C., Gajanan, S. N. \& Sanyal, P. (Eds.) Food Security, Poverty and Nutrition Policy Analysis. Statistical Methods and Applications (2nd ed., pp. 63-91). Cambridge, Massachusetts, Academic Press.

Bunthoeun, C. (2019). Farmers quit pepper amid oversupply. Khmer Times. https://www.khmertimeskh.com/647117/farmers-quit-pepper-amid-oversupply/

Coppock, J. D. (1962). International Trade Instability. McGraw Hill, New York, USA.

Cuddy, J. D. A., \& Valle, P. A. D. (1978). Measuring the Instability of Time Series Data. Oxford Bulletin of Economics and Statistics, 40(1), 79-85. https://doi.org/10.1111/j.1468 0084.1978.mp40001006.x

Department of Statistic Malaysia. (2019). Sarawak Statistics Year Book 2019, (December).

Entebang, H., Wong, S. K., \& Mercer, Z. J. A. (2020). Development and performance of the pepper industry in Malaysia: A critical review. International Journal of Business and Society, 21(3), 1402-1423.

Gulick, J. V. (2018, October 30-31). Crop Report-Pepper. Paper presented at the ESA Conference, Florence, Italy. International Pepper Community. (2019). Pepper statistical yearbook 2019,(172).

Gouel, C. (2016). Trade Policy Coordination and Food Price Volatility. American Journal of Agricultural Economics, 98(4), 1018-1037.

Grega, L. (2002). Price stabilization as a factor of competitiveness of agriculture. Agricultural Economics 18(7), 281-284.

Khalid, A. R., Wong, S. K., \& Alias, R. (2007). Pepper industry. In M. A. Fatimah, R. A. Nik

Mustapha, K. Bisant, \& M. A. Amin (Eds.), 50 years of Malaysian Agriculture: Transformational Issue, Challenges \& Direction (pp.442-473). Serdang, Malaysia: Penerbit Universiti Putra Malaysia. 
Kalidas, K., Mahendran, K., \& Akila, K. (2020). Growth , Instability and Decomposition Analysis of Coconut in India and Tamil Nadu, Western Tamil Nadu, India: A Time Series Comparative Approach, 26(3), 59-66. https://doi.org/10.9734/JEMT/2020/v26i330238

Liew, S. (2020). Lower pepper production expected this year. The Star.https://www.thestar.com.my/business/business-news/2020/09/28/lowerpepper production-expected-this-year

Malaysian Pepper Board. (2018). Laporan Tahunan MPB 2018, 1-27.

Nair, K. P. (2020). The Geography of Black Pepper (Piper nigrum). The Geography of Black Pepper (Piper nigrum) (Vol. 1). https://doi.org/10.1007/978-3-030-52865-2

Nimbrayan, P. K., Bhatia, S. J. K., \& . H. (2019). Growth and Instability in Area, Production and Productivity of Barley in Haryana vis-à-vis India. Current Journal of Applied Science and Technology, 35(6), 1-8. https://doi.org/10.9734/cjast/2019/v35i630210

Sivaraman, K., Kandiannan, K., Peter, K. V., \& Thankamani, C. K. (1999). Agronomy of black pepper (Piper nigrum L.) - a review. Journal of Spices and Aromatic Crops, 8, 1-18 LAEnglish. https://doi.org/10.1017/CBO9781107415324.004

Sukmawan, A., \& Hyesun, Jang (2020). "Global Production Surplus Brings Down Indonesian Pepper Prices". Tridge Analysis. https://www.tridge.com/stories/global-productionsurplus-b rings-down-Indonesian-pepper-prices

Sunandini, G. P., Paul, K. S. R., \& Irugu, S. D. (2020). Analysis of Trends, Growth and Instability in Rice Production in Andhra Pradesh. Current Journal of Applied Science and Technology, 39(42), 40-46. https://doi.org/10.9734/cjast/2020/v39i4231129

Sunge, R., \& Ngepah, N. (2020). The Impact of Agricultural Trade Liberalization on Agricultural Total Factor Productivity Growth in Africa. International Economic Journal, 34(4), 571-598. https://doi.org/10.1080/10168737.2020.1836671

Troster, B. (2018). Commodity price stability: The need for a policy mix that break the visious cycle of commoidity dependence and price volatility. OFSE Policy Note No. 20/2018. http://hdl.handle.net/10419/175086 